\title{
Guesstimating Coastal Ecotourism in Muara Beting, Indonesia
}

\author{
Hengky, S. H. \\ Universitas Bina Darma, Prasetiya Mandiri, SHINE Institute \\ E-mail: hengky_halim@yahoo.com.au
}

Received: August 23, 2017

Accepted: Sep. 29, 2017

Published: October 30, 2017

doi:10.5296/jmr.v9i4.8108

URL: https://doi.org/10.5296/jmr.v9i4.8108

\begin{abstract}
There is a very beautiful beach in an industrial city that located very close to the international airport and the capital of Indonesia. This beach is located amid traffic density and densely populated. This beach is included in the regional tourism development program. This study aims to respond to Master Plan statements and programs from provincial tourism and assess the performance of the coast. The results of these assessments become the basis of improving the performance of coastal ecotourism, which is the hope of the tourists. Currently, the coastal performance almost meets the requirements of coastal ecotourism. This one-year research done by mixed mode method. Data collections processed by random and stratified sampling. This study finds the expected performance of tourism with the concept of ecotourism. There is a gap between performance expectations and current. The performance increases by sett the top priority to the interests in the local economic contribution. Culinary ecotourism builds the economic contribution by community-empowerment and ecotourism social communication. The activity also raises funds of the conserve of mangrove forest with the participation in local communities.
\end{abstract}

Keywords: Coastal-ecotourism, Culinary-ecotourism, Community-empowerment, Ecotourism-social-communication 


\section{Introduction}

Local Regulation no 15 - 2015, on Master Plan of Tourism Development of West Java Province (MPTDWJP) stated that in 2016 - 2025 has divided the tourism destinations of West Java Province into five provincial tourist destinations (PTD). One of the five destinations is Karawang Tourism Destination - Bekasi. Its surround with the center of PTD is Bekasi Regency.

Muara Beting Beach is arguably one of the beaches in Bekasi that has beauty. No one thought that in Bekasi is famous for this industrial area it also has a very beautiful beach. This area previously known as a crowded area and even jammed with a vehicle. Coupled with congestion and air pollution are also building factories are increasingly scattered in this region. However, who would have thought behind the hustle and bustle of this city, the tourists could still enjoy a beautiful beach resort area is in this area. Its name is Pantai Muara Beting, which has charmed scenery (Ardian, 2012).

On the other hand, the Head of Environmental Office of Bekasi (HEOB) city, said that is still four companies that allegedly pollute the area in this area. Allegedly, the company dispose of waste directly to Kali Bekasi without proper processing. Four other companies have not been inspecting by surprise. Meanwhile, there are 14 companies that they have examined, three of which sealed. Moreover, there was abrasion in Beting Beach Village, Muara Gembong Sub-district, Bekasi Regency. It is getting worse (Senja, 2017).

Furthermore, if this condition is allowed to continue. It could damage the water circulation and pollute the environment around the watershed. This became the beginning of water conservation disorder affecting the quality of seawater and biota living around it. This study aim is to respond the statement of MPTDWJP, and tackled on HEOB's business by guesstimating the performance of coastal ecotourism in Muara Beting.

\section{Literature review}

\subsection{Ecotourism sustainability communications}

Ecotourism sustainability communications (ESC) are useful for addressing sustainability issues in key areas, including educational, marketing and networking activities in Ecotourism areas. ESC helps businesses in preventing environmental degradation. Such communication encourages better implementation on a sustainable basis of the form of community training for local communities, especially in the younger generation. Social Communication (SC) does not need adjustment with the ecotourism, regardless of the performance of a small number of business owners who are more knowledgeable. These ecotourism service providers successfully engage young people and communities in managing wetlands in an environmentally responsible manner. Local economic improvements such as culinary activities supported by a culinary ecotourism (Attemene, 2017; Prasita and Rosana, 2017).

\subsection{Coastal Ecotourism}

As many as $60 \%$ of the world's population live in coastal areas that make coastal erosion a global problem. The beach holds various formations due to coastal erosion. Coastal 
ecotourism (CE) developed conservation is one of the safeguards taken against coastal erosion. The populated beaches and have experienced and seen the extent that coastal erosion and coastal shoreline changes. They may have influenced people's perceptions, coastal users, researchers, and coastal managers. These conservation efforts tend to increase their awareness of coastal processes and their impact (Armono, Rosyid, and Nuzula, 2017; Farrugia, 2017).

The expansion and development of ecotourism areas is a complex phenomenon and needs to study interdisciplinary. Currently, the development of tourist areas is increasing rapidly. The expansion of CE's area has a close relationship between sustainability, environmental carrying capacity and the limits of tourist growth. These three aspects considered in the management of ecotourism. The ecotourism management uses the concept of carrying capacity of coastal tourism activities that include beach tourism, snorkeling, diving, and mangrove forest tours (Nuzula, Armono, and Rosyid, 2017).

The natural beauty of the coast are not only reflected on the sea, but also on land. Large white sand ready to spoil the eyes of anyone that set their foot of it. Beach that has its own uniqueness, its location is also strategic to accelerate the development of tourism. CE gaps between the archipelago show that local governments and tour operators can improve the visual aesthetic atmosphere around coastal areas. It can enhance the beauty of the coastal environment landscape towards the visualization of tourists by ESC in enjoying the natural theme along the coastline that is complemented by culinary tourism (Hengky, $2017 \mathrm{a}, 2017 \mathrm{~b}$, 2017c; 2017d; 2017e; Pace and Morgan, 2017; Porter, Orams, and Lück, 2015; Sakata and Prideaux, 2013).

Development of moderate mediation modelled on natural capital where emotional value serves as an intervention mechanism in the relationship between nature and $\mathrm{CE}$. The tourists give support to this program by crossing the various dimensions of natural capital. Mediation from the socio-cultural and economic dimensions has a positive impact on ecology and their ecotourism intentions. The moderate effect of emotional value depends on the ecological benefits caused by economic benefits. Emotional value fosters a moderately positive effect of economic benefits of ecotourism intent as it reinforces the positive relationship between intrinsic motivation and ecotourism value perception (Liu and Huang, 2017; Picard, 2007, 2015; Rhormens, Pedrini and Ghilardi-Lopes, 2017).

CE development can alter the natural dynamics of coastal environments and have strong implications for marine life. Turtle nests are on the ocean shore and often depend on specific conditions. Development in coastal areas affects coastal environments with the distribution of animal and biota living locations in the region. Additional coastal development based on a mixed artificial management plan to support the emerging tourism industry can degrade coastal attractiveness and quality. Conversely, culinary tourism can actually improve the convenience of coastal ecotourism activities (Roe, Clune, and Paladino, 2013; Rusli, Santosa, and Soemarno, 2015).

Coastal erosion poses a significant threat to coastal economic growth and environmental impacts. The market for tourism services is a key factor of coastal economic growth. 
Evaluation of the CE's economic implications of coastal erosion is useful for addressing coastal protection costs taking into account income losses. The vulnerability of coastal erosions of expecting land loss and the relevant value of economic activity greatly affected economic growth of a combined environmental and economic approach along coastal areas. The value of the eroded coast, which is capitalized on revenue from tourism business, is determined by its breadth and tourism business. Realistic cost-benefit scenarios of stakeholders and related policy makers help them to prioritize and allocate budgets and benefits from the point of view of coastal governance (Alexandrakis, Manasakis, and Kampanis, 2015; Garland, Wells, French, and Dawkins, 2017).

A variety of coastal resources that could potentially be developing as ecotourism areas with coastal landscape planning for community-based CE areas. Assessment of the potential for ecotourism objects and attraction is indispensable for maintaining the suitability of the coastal landscape and the carrying capacity of the coastal environment. Assessment of potential objects and attractions using modification methods. Meanwhile, to assess the suitability of ecotourism areas and carrying capacity using coastal ecotourism standards. Object ecotourism and assessment of the attraction shows that coastal areas have a variety of coastal ecotourism attractions with potential categories and less potential. Ecotourism activities planned include ecosystem observation tours, camping, boat, swimming, diving, snorkelling, fishing, and photo hunting. The facility is a tourist information, restaurant, hotel-homestay, view a tower, toilets, tourist interpretation board, and souvenir centred. To protect the coast as a tourist area, the government must have the rules and policies of conservation area. Community participation should be encouraged to provide economic opportunities for local communities (Chien, 2016; Hadi and Nurisjah, 2012; Liu and Huang, 2017).

Aspects of CE's inter-population relationships between the six villages within the environment that have environmental economic activity were involved in the interpretation, environmental and conservation notions proposed by the biosphere reserve. The human program - a biosphere distributed by biosphere reserves, practiced in the field. In particular, environmental economic activities carried out by integration program - acceptance and internalization of conservation principles. This activity contributes to the crystallization of new conservation spaces (Carrier and Macleod, 2005; Doyon and Sabinot, 2014).

However, CE is travelling to the visual aesthetic of the coastal landscape; ESC in enjoying the natural theme along the coastline; complemented by culinary tourism (CT); conserved coastal environment; community participation; local economic improvements (Alexandrakis et al., 2015; Hadi and Nurisjah, 2012; Hengky, 2017 a, 2017b, 2017c; 2017d; 2017e; Liu and Huang, 2017; Roe et al., 2013).

\section{Methodology}

This mixed mode (quantitative and qualitative) research has conducted on the coast of Muara Beting Bekasi for a year from October 2015 - November 2016 (Cohen, 1960; Gottschalk, 2013; Tong, Sainsbury, and Craig, 2007; Henderson, 1991). 270 questionnaires were distributed randomly and stratified sampling. The respondents consist of local people, travel 
agents, tourists and international tourists, local tourism departments, HEOB staff, related institutions.

Interview technique using technique triangulation and Focus Group Discussion (FGD). The FGD is a pre-determined semi-structured interview for CE led by a skilled moderator. Moderators asked broad questions to get responses and generated discussions about the participants (Tong, Sainsbury and Craig, 2007, McLafferty, 2004).

The data collected tabulated by using content analysis (Cohen, 1960; Gottschalk, 2013; Henderson, 1991) - SAS text miner that focuses CE (Alexandrakis et al., 2015; Hadi and Nurisjah, 2012; Hengky, 2017 a, 2017b, 2017c; 2017d; 2017e; Liu and Huang, 2017; Roe et al., 2013).

Furthermore, this study analyzed each of its attributes based on the Kappa = K. NIlai K coefficients that met the CE requirements (Cohen, 1960; Gottschalk, 2013; Henderson, 1991). Moreover, this study discusses the problems affecting each factor of the CE. Some of them are more important, and the others less important. Finally, this study analyzes future CE opportunities and strategies that should be take to make it strengthen the performance.

\section{Discussion}

The results of this study indicate that the performance of CE in Muara Beting (CEMB) at present (Table 1$)$ is almost environmentally friendly $(\mathrm{K} 1=0.5704)$. The main performance advantage is ESC in enjoying the natural theme along the coastline (0.2149). The second performance advantage is traveling through the aesthetic visual of the coastal landscape (0.1818). It is a journey to enjoy the natural beauty of the coast to be an attraction for the tourists. The third advantage are the conserved coastal environment. This absolutely done with its wake up the quality of the coastal environment. It could enhance the beauty and attractiveness of a natural CE. The fourth advantage, community participation (0.1548). Community participation is indispensable. They could maintain the quality of the coastal environment and its cleanliness. This can increase the comfort of tourists in the tour. Evenmore, around the coast there is equipped with culinary tourism (0.1484). This can improve the economics of coastal communities (0.1429).

Table 1. Existing performance of CE in Muara Beting

\begin{tabular}{|l|r|r|}
\hline CE in Muara Beting & Value & \% Freq \\
\hline Travelling to the visual aesthetic of the coastal landscape & 28 & 0,1806 \\
\hline ESC in enjoying the natural theme along the coastline & 33 & 0,2129 \\
\hline Complemented by culinary tourism & 23 & 0,1484 \\
\hline Conserved coastal environment & 25 & 0,1613 \\
\hline Community participation & 24 & 0,1548 \\
\hline Local economic improvements & 22 & 0,1419 \\
\hline
\end{tabular}

Koefficient Kappa $=\mathbf{K}_{\mathbf{1}}=\mathbf{0 . 5 7 4 1}$ 
Table 2. Expected performance of CE in Muara Beting

\begin{tabular}{|l|r|r|}
\hline CE in Banyuwangi & \multicolumn{1}{|c|}{ Value } & \% Freq \\
\hline Travelling to the visual aesthetic of the coastal landscape & 31 & 0,1582 \\
\hline ESC in enjoying the natural theme along the coastline & 30 & 0,1531 \\
\hline Complemented by culinary tourism & 34 & 0,1735 \\
\hline Conserved coastal environment & 32 & 0,1633 \\
\hline Community participation & 33 & 0,1684 \\
\hline Local economic improvements & 36 & 0,1837 \\
\hline
\end{tabular}

Koefficient Kappa $=\mathbf{K}_{\mathbf{2}}=\mathbf{0 . 7 2 5 9}$

This study further resulted in the expected performance of CEMB (Table 2) indicating that there was a change of priority to local economic improvements that from the last priority changed into the first priority (0.1837). It indicated that with the increasing economic contribution to CEMB activities increased together from complementing by culinary tourism (0.1735). This activity made by involving community participation $(0.1684)$. They could maintain the coastal environment (0.1633). Therefore, the tourists become more interest in the beach that maintained the quality of the environment (0.1582). It may enhance ESC aesthetic beauty of the coastal landscape $(0.1582)$.

\subsection{Local economic improvements}

Refer to the importance of local economic improvements (Table 2). Increased economic contribution can start from complementing CEMB with culinary tourism (CT) followed by community participation in conserved coastal environmental programs. This improves their welfare and on improving economic growth to increase financial availability for coastal environmental conservation efforts. In addition, local revenue (LR) increased. The increase in LR used to support infrastructure development in the coastal environment.

\subsection{Complemented by culinary tourism (CT)}

A realistic step that done by equipping CE, this study discusses more in depth about CT that supported by a community-empowerment and ESC. Near the beach, there are several such culinary vegetable catfishes, Dodol Bekasi, Snake Getok, and Coconut Root. CT becomes the driving force of the coastal economy. Therefore, this section discussed more deeply.

\subsubsection{Vegetable catfishes}

Each region, of course, has a menu and taste different. For the travelers, tasting the typical culinary of a region is a mandatory and fun activity. As an area located in the middle, Bekasi has a distinctive culinary Vegetable Pucung. Much like typical Jakarta food, it has little influence of Betawi and Sundanese. Vegetable catfishes Pucung is a catfish cooked by using Kluwek. It produced black sauce. The delicious - unique taste is perfect. They eat it with warm white rice and spicy sauce. The soft texture of the fish and its sauce mixed with a lime juice that made it taste good (Fajri, 2017). 
Currently, vegetable catfish Pucung menu rarely found, due to the difficulty of getting it. It is difficult to be empowered because of the greedy nature of fish. To feed the fish is not proportional to the result. While, the habit of this fish lived in the swamp or there is now no more swamps around this area. It is difficult even cannot be cultivated in a breeding pond. Usually, they captured directly from nature that now rarely found. A number of areas of this fish supplier come from Bandar Lampung, Palembang and Bengkulu. The fish production of the island is very abundant. This fish had also been supplying to the city of Bekasi known to have typical food.

A number of typical cork foods stalls always crowded around visitors. Although, the typical cork culinary today is not practically cheap. However, the vegetable menu can still found in some restaurants in this area. One of them is the typical food of this area. It got Indonesian World Records Museum. This food served as many as 3000 portions distributed by the mayor of Bekasi. The resulting sauce is similar to Rawon, which is typical of Surabaya food, but vegetable cork Pucung has taste and main ingredient different from Rawon that uses beef as the main ingredient. While, the vegetables are using cork fish

\subsubsection{Dodol Bekasi}

Dodol is indeed one of the typical food of Bekasi that is widely known to the public. This legit food favored by tourists. Its flavor variants are also growing according to the time. Various its' variants of original flavor, black sticky, Durian, original sesame, black sesame black, there Geplak, diamonds and other typical foods such as pickled and Pletok beer. Two Kenjeng of a large brass material each containing the Red Sugar and Black sticky rice cooked. The process of stirring one Kenjeng takes four hours. On the other hand, mangrove can also be use as mangrove Dodol and refreshing mangrove juice (Sejati, 2013).

\subsubsection{History of Dodol}

Dodol Bekasi is a type of typical food of the Betawi tribe. It is brownish-black with less flavor variation than it from other regions. The flavor consists only of white sticky rice, black sticky rice, and durian. The process of making it is very complicated. The manufacture substances consisting of glutinous rice, brown sugar, granulated sugar and coconut milk should be cook on the stove with wood firewood for 8 hours. It is generally make as a special snack for the party, the month of Ramadan, or Eid al-Adha. Especially before the feast, it sold well. Because of it complicated manufacturing process, only a few people are skilled at making it. At that time, large families of the community around their life close together, and the process of making their lunkheads complement each other the basic ingredients of the manufacture. Once, the material is available, the men tasked with making it and stirring the dough. While, the women prepare all the materials needed in the process of making it. On waiting for the maturity, the girls and women prepare the food for breaking the fast, after cooking it directly distributed it to the fair and equitable according to how much the family that contributed to the making of it. 


\subsection{Making process}

It is not easy to make a Dodol. The residents apply the principle of mutual help (splice) that it can be create properly. The materials used are sticky rice, brown sugar, sugar and coconut milk. Good materials can make it delicious and durable. According to the seller, it newly created and can last up 2 weeks at room temperature. The seller even forbade him to put them into the refrigerator.

\subsection{Mutual Cooperation Principle in Making Dodol}

Firstly, the woman prepares the ingredients, shreds the coconut that peeled by the man to get the coconut milk, pounding glutinous rice to make the flour. Secondly, pour all the mixture of ingredients of the swamp (big frying). It started thick, and then replaced it by stirring. The stirring process takes a long time, between 8-12 hours without stopping using a wooden stirrer. Thirdly, the fuel to cooking it is firewood that must be keep so as it did not overheat and smoke. Fire that is too large will make it and cook uneven. Smoke can absorb in it and make it feel bad. It has been cook poured on a tray or winnow out cool. Then the women do the final task of cutting it so small and wrap it.

A culinary that sometimes escaped the news, Bekasi has a culinary that is also delicious. The area Swatantra Wibawa Mukti in Bekasi district, there is a house which is at once factory making. This independent entrepreneur is so determined to expand its business, without the help of banking institutions. However, thanks to his diligence to develop the business since 1999. Thanks to diligence and patience, Lunkhead Bekasi which it production penetrated to the area around Bekasi and Jakarta.

\subsection{ESC, Promosi Getok Ular}

There are many promotional systems, can be through radio, television, newspaper ads or pairs of banners on the street with easy to read position, but because of its business activities is only small and medium entrepreneurs, such a promotion cannot be done. They introduced their wares product of a very conventional way called Snake Getok or promotion of mouth-to-mouth. The consumers feel satisfy then they automatically inform the privileges of it. Bekasi is on his friends. Not easy, is one word that describes the effort that pioneered. Deciding to cultivate culinary business at the beginning of the millennium, many obstacles faced by the mother of this pilgrimage, ranging from the difficulty of marketing it in Bekasi until the limitations of capital. It is usually only consumed at a certain time such as before Ramadan or Idul Fitri. Another obstacle is the supply of bundles that sometimes are stuck. With a strong will, the business began to demand. To add knowledge about the processing, they also followed a train of instructors that imported from Bandung. Since then, their business has been growing, especially according to the story of Haji, who this year is even sixty years old, Bekasi local government provides equipment such as cauldrons, stoves, flour grinders and coconut tools.

Currently, Ms.Rodiah is the only female businesspersons that are in the business in Bekasi. Her efforts seriously and hard work accompany success. She grasped the key to success with hard work and her efforts to continue introducing it in Bekasi with various ways, both with 
marketing techniques and by following the exhibition for it homemade and well known by the public of Bekasi and the surrounding the areas (Irawan, 2015).

Not infrequently from the system, it started penetrating a number of major cities in Indonesia such as Batam, Karawang, and Jakarta. Even according to the persistent businessperson that lives in Suka Rukun, Suka Tani Bekasi. Their products exported to Saudi Arabia. With a marketing base of the holy land of Mecca, also Malaysia neighbor country. Usually it sent out of the area by the fans.

\subsection{Creating Economic Chain}

As their production capacity increases, they need more substances. To maintain the quality, they prepared a number of strategies. In order to feel more distinctive its smell, then they also use firewood. They chose firewood from a place called Pulo Wren in the Bekasi area. In addition, they obtained a number of main raw materials for the manufacture such as black rice, brown and white sugar, derived it from the surrounding area of Bekasi. The effort ultimately creates an economic chain that can be enjoyed by the people around Suka Rukun area where is processed and made by him. This synergy is mutually beneficial to the creation of employment opportunities for people that are around the factories. This business is actually a business that can alleviate the economy. It is also very appropriate to be a food that became trademark Bekasi district.

\subsection{Dodol packaging}

Dodol is a compulsory snack of Bekasi society at the time of Eid. Usually, this cake made busy with the end of fasting-month. Now it increasingly difficult to find. It is only in the villages that are still a regional tradition. However, other entrepreneurs are loyal to make it to this day. It contains a very deep philosophy of making it. The people can interact, chat and share. Even the myth, it should not say carelessly and act recklessly. It is a symbol of prestige. The cost of manufacture is expensive and through a long process. Therefore, people make it collectively and chatting. Today there are various flavors, including banana tape, jackfruit, and Duren. The packaging is no longer a slab, has made wide range of box to round. However, not all that reduces the taste. Excess it made without preservatives, its durability can be up to six months even a year. Therefore, if it sent abroad, it will not be stale or moldy. Dodol entrepreneurs are not merely pursuing profits. They feel obliged to preserve the typical food of Bekasi that currently almost displaced by various factory-made biscuits. They hope that local governments can help promote it.

Dodol after processed, it will be formed into a package like cylinder, wrapped in a plastic sheet and tied with a yarn. This packaged still used for it. In the future, they hope it can be packed with packaging that is much more interesting and the look of it modern nuances, this is the fruit of their mind. They hope it able to become a culinary icon Bekasi district and the packaging more attractive than it does. 


\subsection{The Meaning of the Production Process}

Referred from the story from the process of making it mentioned above, it has an implied learning and contains the social meaning of mutual help, joy and spirit of unity needed in this culinary process. It always reflected on the life of the local people that can work in a team with the aim at strengthening the bonds between kinship. The sweet and chewy taste of it will always remind us that in a harmony - cooperation, there is harmonization that can form a harmony of life for the lovers of the Indonesian traditional culinary world. Even though, it looks not easy in the process, it is a traditional culinary that always sought as a complement of the modern culinary dish (Sejati, 2013).

\subsection{Coconut Root (Akar Kelapa) _}

Typical food during Lebaran is very much manifold. Surrounding community, there is snack such as Dodol, Rangginang, Tape Uli, and Coconut Root Cake. They can still be seeing at the original Bekasi residents table during Lebaran. It's just snacks, not other foods that can fill like, stews milkfish, Ketupat vegetables and vegetables Lodeh Cecek made from young jackfruit in mixed Pete, and Jengkol stem. Coconut Root Cake, which currently somewhat reduced, made the residents. In addition, to make specifically, the manufacturer also never produce it. In contrast, one of the original Bekasi community said that they did not know the originally. It was a coconut root cake that clears since the time of their grandfather already there. They did not know it made. Therefore, they cannot explain the founder. It seems to have to decorate the table matched with Rangginang - onion fried nuts, when "Eid" arrives (Suseno, 2015).

\subsection{Conserved coastal environment}

On this beach, tourists can along the mangrove forest area located not far from the coast. They can find a conservation area of mangrove forests that are wide-ranging. The total area are about 70 hectares. In this beach, there are several types of mangrove plants, namely Rhizophora Stylosa Griff (red mangroves), Xylocarpus Moluccencis, Avicenna (fire-tree). There are also branches of trees that are old enough, dead. It adds to the beauty of the beach. In addition to mangrove forests, Muara Beting Beach area is also often found birds that migrate from the sea of southern china and the Pacific Sea. The location every year there is a storm of typhoons / wound from the Pacific to Southern China in September to February. There is a concentration of migratory birds in this place. There is a rare black monkey too.

Furthermore, they can find many species of birds within this protected mangrove conservation area. They not allowed performing hunting activities or activities to catch other animals who live in the mangrove forest. The beauty of CEMB also adorned with the surrounding mangrove forests, making one of the CE destinations that began ogled by people around the city of Bekasi. Moreover, the location is not too far from the city of Bekasi. That way, they only need to travel time for 2 hours journey by using private vehicle. Nevertheless, road access is good, and wide. Therefore, it can make it easier about them using private vehicles such as cars or motorcycles. 
The existing facilities in the coast may still be incomplete. The tourist area is still in the process of development. There is a basic facility such as parking lots, toilets, and the dressing room in this destination. The beach is actually already quite feasible to be use as a tourist attraction. The area is actually still in the process of development. There are few facilities such as parking lots, toilets, and locker rooms with CEMB.

Furthermore, the abrasion at CEMB is getting worse. To reduce it, the local government planted a thousand mangrove plants in this area. Mangrove plants are very useful to reduce several abrasions in this region. In addition, mangrove planting aims to reduce the abrasion and increase the economic income of the community. The need many mangroves in this region. In addition to mangrove planting, their side did psychosocial assistance in the form of disaster education. Children every school day got nutrition standby packages in place that is flooded due to abrasion.

\subsection{Travelling to the visual aesthetic of the coastal landscape}

Muara Beting Beach is located in the Village of Happy Beach Muara Gembong Subdistrict, Bekasi. This beach is cool to use as a tourist spot. This CEMB is in the process of development as a potential beach tourism object of Bekasi Regency. Conservation areas are also located around this beach. This area also contains mangrove forest area of $70 \mathrm{Ha}$. Here there are many migratory birds from the South China Sea and Pacific Ocean when the location every year the current storm of wind from the Pacific to Southern China in September to February. The natural phenomenon causes the concentration of migratory birds in this place. In addition, the birds there is also a rare black monkey. Furthermore, CEMB sand is slightly brown. At least, this beach can treat the tourists that describe the beach atmosphere. Moreover, the beach scene here is also quite charming. CEMB is a landau beach with sand slightly brown sea with the waves breaking. It likes a harmonious voice that pacified the soul (Satrio, 2015).

\subsection{ESC in enjoying the natural theme along the coastline}

Facilities available on this beach are still not complete. This is because the area of CEMB is actually still in the process of development. Nevertheless, there are basic facilities on this beach such: parking lots, toilets, and a changing room. This beach is quite feasible to serve as a tourist attraction. This one beach is one of the most beautiful beaches owned by this area. The tourists can go with the family really enjoy the beautiful beach here with the sand that is white-brown.

In addition to the charming natural scenery, they can still find other interesting things. This beach is a conservation of mangrove forest and a home for migratory birds from the South China Sea and the Pacific Ocean. For birdwatchers and hobbies with birds, this beach can be the most beautiful beach for them. Birds are usually easy to find in September and February. Not only birds that they can find conserved this mangrove. They can find rare animals here like black monkeys. There is a mangrove forest on this beach is a place to live black langur.

They can explore the beauty and interesting things on this beach. The satisfaction with nature tourism here. These attractions are equipped with various facilities and facilities to facilitate 
them, such as changing rooms, parking, to the restaurant. Here they can also find vast mangrove forests. Inside there are several kinds of fauna such as local birds and black langur. In addition, these forests there are also pond ecotourism. Communities around the coast also rely on living from the cultivation of shrimp ponds, fish, and seaweed.

\section{Conclusion}

The results of this study respond to statements from provincial tourist destinations (PTD) that plan the five coastal tourism areas. One of the five destinations is Muara Beting beach (MBB). Furthermore, this research reveals the readiness of coastal tourist destinations today in MBB is natural. It almost met the requirements of coastal ecotourism. This beach performance improved on the concept.

Moreover, there is a gap between existing and expected conditions based on the concept of ecotourism. The performance is distinct from its expected. It increased after prioritizing local economic improvement factors by increasing culinary ecotourism efforts that add to the attractiveness of coastal ecotourism in this area.

Realistically, it done by empowering the local community on enhancing culinary ecotourism. It is like culinary vegetable catfishes, Dodol Bekasi, Snake Getok, and Coconut Root. The CT developed economic contribution to local government on supporting the mangroves' conservation program. Empower the community supported mangrove conservation programs. It would be other economic contribution to the local people. The program would develop mangrove forest ecotourism. It is another economic contribution to them and at the same time, it conserved the beach abrasion. Moreover, they promoted it by ESC program. It enhanced stakeholders' knowledge on managing natural resources along the coast.

\section{References}

Alexandrakis, G., Manasakis, C., \& Kampanis, N. A. (2015). Valuating the effects of beach erosion to tourism revenue. A management perspective. Ocean \& Coastal Management, 111, 1-11. https://doi.org/10.1016/j.ocecoaman.2015.04.001

Ardian, D. (2012). Estuary Beting, This is Bekasi's Own Beach, Detiktravel. Retrieved from https://ravel.detik.com/destination/d-1980771/muara-beting-inilah-pantai-milik-bekasi

Armono, H. D., Rosyid, D. M., \& Nuzula, N. I. (2017). Carrying Capacity Model Applied to Coastal Ecotourism of Baluran National Park, Indonesia. In IOP Conference Series: Earth and Environmental Science, 79(1), 012004. https://doi.org/10.1088/1755-1315/79/1/012004

Attemene, P., \& Eguavoen, I. (2017). Coastal ecotourism in The Gambia: Effects of sustainability communication on environments and rural livelihoods (No. 154). ZEF Working Paper Series.

Carrier, J. G., \& Macleod, D. V. (2005). Bursting the bubble: The socio - cultural context of ecotourism. Journal of the Royal Anthropological Institute, 11(2), 315-334. https://doi.org/10.1111/j.1467-9655.2005.00238.x

Chien, M. C. (2016). An empirical study on the effect of attractiveness of ecotourism 
destination on experiential value and revisit intention. Applied Ecology and Environmental Research, 15(2), 43-53. https://doi.org/10.15666/aeer/1502_043053

Cohen, J. (1960). A Coefficient of Agreement for Nominal Scales. Educational and Psychological, 20, 37-46. https://doi.org/10.1177/001316446002000104

Doyon, S., \& Sabinot, C. (2014). A New'Conservation Space'? Protected Areas, Environmental Economic Activities and Discourses in Two Yucatán Biosphere Reserves in Mexico. Conservation and Society, 12(2), 133. https://doi.org/10.4103/0972-4923.138409

Fajri, F. A. (2017). The existence of Culinary Culinary Pucung Khas Bekasi Threatened, This Cause, Warta Kota. Retrieved from http://wartakota.tribunnews.com/2017/09/17/eksistensi-kuliner-gabus-pucung-khas-bekasi-ter ancam-ini-sause

Farrugia, M. T. (2017). Public perceptions on coastal erosion in the Maltese Islands: a case study of St George's Bay (St Julians) and Pretty Bay (Birżebbuga). Natural Hazards, 86(2), 587-604. https://doi.org/10.1007/s11069-017-2775-9

Garland, L., Wells, M., French, K., \& Dawkins, J. (2017). Rainforest to Reef: A Landscape-scale Approach to Coastal Ecotourism in Malaysia.

Gottschalk, L. A. (2013). Content Analysis of Verbal Behavior: New Findings and Clinical Applications, Routledge, 19-22

Hadi, S., \& Nurisjah, S. (2012). Landscape planning for community-based ecotourism at coastal areas of paloh distric, West Kalimantan.

Henderson, K. (1991). Dimensions of Choice: A Qualitative Approach to Recreation, Parks, and Leisure Research. Venture. State College. Australia.

Hengky, S. H. (2017a). Beholding Tanjung Pesona Coastal-ecotourism in Bangka Islands, Indonesia. Business and Economic Research, 7(2), 102-117.

Hengky, S. H. (2017b). Gazing Coastal Ecotourism in Morotai Islands, Indonesia. Environmental Management and Sustainable Development, 6(2), 144-157. https://doi.org/10.5296/emsd.v6i2.11393

Hengky, S. H. (2017c). Presiding Ora Coastal Ecotourism in Maluku, Indonesia. Business Management and Strategy, 8(2), 27-44. https://doi.org/10.5296/bms.v8i2.11827

Halim, H. S. (2017d). Scrutinizing Coastal Ecotourism in Gili Trawangan, Indonesia. International Journal of Marine Science, 7.

Hengky, S. H. (2017e). Probing Coastal Eco-Tourism in Pasir Putih Beach, Indonesia. Business and Management Horizons, 5(1), 1. https://doi.org/10.5296/bmh.v5i1.10606

Irawan, T. (2015). Haji Rodiah, Abstinence Surrender with Effort Dodol Bekasi, Kompas. Retrieved

from 
https:/www.kompasiana.com/topikirawan/haji-rodiah-pantang-menyerah-dengan-usaha-dodo 1-bekasi_556c48e6c823bdcf048b4567

Liu, C. H., \& Huang, Y. C. (2017). A natural capital model of influences for ecotourism intentions and the buffering effects of emotional values. Journal of Travel \& Tourism Marketing, 34(7), 919-934. https://doi.org/10.1080/10548408.2016.1251375

McLafferty, I. (2004). Focus group interviews as a data collecting strategy. Journal of advanced nursing, 48(2), 187-194. https://doi.org/10.1111/j.1365-2648.2004.03186.x

Nuzula, N. I., Armono, H. D., \& Rosyid, D. M. (2017). Management of Baluran National Park Resources for Coastal Ecotourism Based on Suitability and Carrying Capacity. In Applied $\begin{array}{llll}\text { Mechanics and } \quad \text { Materials, } & \text { 862, }\end{array}$ https://doi.org/10.4028/www.scientific.net/AMM.862.161

Pace, N. L., \& Morgan, N. (2017). Living Shorelines: Eroding Regulatory Barriers to Coastal Resilience. Natural Resources \& Environment, 31(3), 44.

Pedrini, A. D. G., \& Ghilardi-Lopes, N. P. (2017). Implementation feasibility of a marine ecotourism product on the reef environments of the marine protected areas of Tinhare and Boipeba Islands (Cairu, Bahia, Brazil). Ocean \& Coastal Management, 139, 1-11. https://doi.org/10.1016/j.ocecoaman.2017.01.022

Picard, D. (2007). Potential and feasibilities of national and local development of coastal ecotourism, Regional Strategic Action Plan for Coastal Ecotourism Development in the South Western Indian Ocean, 10-11.

Picard, D. (2015). Making ecotourism sustainable: refocusing on economic viability. Lessons learnt from the "Regional strategic action plan for coastal ecotourism development in the South Western Indian Ocean". Journal of Sustainable Tourism, 23(6), 819-837. https://doi.org/10.1080/09669582.2015.1019512

Porter, B. A., Orams, M. B., and Lück, M. (2015). Surf-riding tourism in coastal fishing communities: A comparative case study of two projects from the Philippines, Ocean \& Coastal Management, 116, 169-176. https://doi.org/10.1016/j.ocecoaman.2015.07.015

Prasita, V. D., \& Rosana, N. (2017). Dynamic Model of Land Area Changes in the East Coast of Surabaya. In Applied Mechanics and Materials, 862, 138-143. https://doi.org/10.4028/www.scientific.net/AMM.862.138

Rhormens, M. S., Pedrini, A. D. G., \& Ghilardi-Lopes, N. P. (2017). Implementation feasibility of a marine ecotourism product on the reef environments of the marine protected areas of Tinharé and Boipeba Islands (Cairu, Bahia, Brazil). Ocean \& Coastal Management, 139, 1-11. https://doi.org/10.1016/j.ocecoaman.2017.01.022

Roe, J. H., Clune, P. R., \& Paladino, F. V. (2013). Characteristics of a leatherback nesting beach and implications for coastal development. Chelonian Conservation and Biology, 12(1), 34-43. https://doi.org/10.2744/CCB-0967.1 


\section{Macrothink}

Journal of Management Research

ISSN 1941-899X

2017, Vol. 9, No. 4

Rusli, Santosa, H. R., \& Soemarno, I. (2015). Coastal ecotourism-based development for fishermen settlement in Labuan Bajo, Donggala, Central Sulawesi, International Journal of Development Research, 5 (08), 5215-5221

Sakata, H., \& Prideaux, B. (2013). An alternative approach to community-based ecotourism: a bottom-up locally initiated non-monetised project in Papua New Guinea, Journal of Sustainable Tourism, 21, 880-899. https://doi.org/10.1080/09669582.2012.756493

Satrio, B. (2015). Beach "Muara Beting" Hidden Tour in Bekasi, Kompasiana. Retrieved from

https://www.kompasiana.com/ubaysatrio/pantai-muara-beting-wisata-terembunyi-di-bekasi_5 6781208b77a61d00af0725d

Sejati, I. K. (2013). Culinary Tour: Making Dodol Betawi, Tourist directory. Retrieved from https://director-wisata.com/wisata-kuliner-pembuatan-dodol-betawi/

Senja, A. M. M. P. (2017). There are four other factories in Bekasi that are suspected of polluting the River, Kompas.com. Retrived from http://megapolitan.kompas.com/read/2017/10/05/08100521/ada-empat-pabrik-lainnya-di-bek asi-yang-diduga-mencemari-kali

Suseno, Y. (2015). Food Lebaran Khas Citizens Bekasi: Coconut Root Cake. Kompasiana. Retrieved from https://www.kompasiana.com/yhu/makanan-lebaran-khas-warga-bekasi-kue-akar-kelapa_550 055eca33311377251081a

Tong, A., Sainsbury, P., \& Craig, J. (2007). Consolidated criteria for reporting qualitative research (COREQ): a 32-item checklist for interviews and focus groups. International journal for quality in health care, 19(6), 349-357. https://doi.org/10.1093/intqhc/mzm042 